\title{
The Effect of Using Educational Games in Teaching Kingdoms of Living Things
}

\author{
Meryem Selvi ${ }^{1, *}$, Ayşe Öztürk Çoşan ${ }^{2}$ \\ ${ }^{1}$ Department of Biology Education, Faculty of Education, Gazi University, Ankara, Turkey \\ ${ }^{2}$ National Education Directorate, Ankara, Turkey
}

Copyright $(2018$ by authors, all rights reserved. Authors agree that this article remains permanently open access under the terms of the Creative Commons Attribution License 4.0 International License

\begin{abstract}
This study aims to investigate the effects of using scientific educational games in teaching Kingdoms of Living Things on students' academic achievement and retention of knowledge. The study also assessed students' perceptions of these educational games. 68 ninth grade students constitute the study group of this research. In the school in which the instruction was carried out two ninth grade classes were randomly assigned as experimental group and control group. The implementation of the study lasted seven weeks as three lesson hours per week. The same method of lecturing was carried out in the experimental and control groups. Review of the topics was made by researcher through the question-answer method and giving the activities in the textbook as homework in the control group. In the experimental group, educational games were used to review, reinforce and assess the topics. At the end of the study the score of posttest and the retention test implemented six month after showed a significant difference in favor of experimental group. The results put forth that educational games enhance students' achievement and are an effective tool in providing the retention of new knowledge. Within the scope of the study, the experimental group students' views on the use of educational games were obtained at the end of implementation, which were generally positive. The students found the games informative, entertaining and reinforcing their learning, and stated that they are effective in enabling the retention of new knowledge, promoting collaboration with their peers, and increasing their interest and motivation for learning.
\end{abstract}

Keywords Educational Games, Biology, Teaching, Retention of Knowledge, Student Achievement, Kingdoms of Living Things

\section{Introduction}

Students of content-rich subjects such as biology are prone to memorizing instead of learning by thorough comprehension. When learning such subject matter, students simply memorize the knowledge without processing it; thus, this knowledge is quickly forgotten. Traditional didactic teaching is a teacher-centered method carried out without any interaction between the teacher and students or among students themselves, and generally leads to boring and ineffective lessons [35]. Students can go beyond memorizing and realize a higher level of thinking only when they test their mental models related to a concept through problem-solving, inquiry, group work, being active with the subject matter. In order for students to achieve such a deep comprehension, educators generally favor classroom activities that encourage active learning [35]. Students can learn more effectively through active learning, a process whereby students directly participate in their own learning by interacting with other students to think critically and bolster the learning of new concepts. During these interactions, students might explain a concept to each other in different ways or express unnoted issues. This is not only a method of review but also a process requiring analysis and critical thinking [26]. Educational games require students' active participation in the learning process.

Educational games are, at the same time, considered an effective alternative to supporting traditional teaching approaches in terms of educators' responsibility, such as inspiring students to learn, teaching them to love learning, and making learning fun [25]. These responsibilities are often neglected in science education because students' motivation towards and participation in lessons is usually a challenging task for in-class teaching, as is still discussed in many studies [16]. However, students become more enthusiastic to learn when learning takes place in a fun and interactive way [34]. Educational games are an interactive approach to boosting active learning and motivation, and encouraging teamwork [30]. Games have an important role in realizing active learning since they include both interactive and distinctive elements [33]. They not only make learning more entertaining but also encourage 
students' in-class participation and foster their attitudes towards learning [18]. Moreover, students who are motivated and included in the teaching method can have a more successful learning outcome, yielding a permanent body of knowledge which can later be recalled [33]. Educators can use games for various purposes such as reinforcing a previously learned topic, teaching new concepts, and motivating students to participate [Kirk as cited in 26]. Educational games can be used at the beginning and end of a lesson. For this reason, they can foster students' interest and motivation towards lessons, or review, reinforce and assess the learned topics. Therefore, educational games promote students' active participation in lessons and thus assist with their learning [36].

There is a great deal of research revealing the influence of educational games on learning. Odenweller, Hsu, and DiCarlo, (1998) indicated that games are successful in promoting the learning of concepts, and that they allow students to discuss target concepts. Ogershok, and Cottrell (2004) suggests that the educational game motivated students to improve their knowledge of pediatric medicine. Cardona, Spiegel, Alves, Ducommun, Henriques - Pons, and Araújo-Jorge (2007) stated that the educational game that used in the study can develop a good teaching approach that helps teach complex content in molecular biology. Olimpo, Davis, Lagman, Parekh, and Shields, (2010) stated that the educational game they used enhance student learning of basic biology terms. Barclay, Jeffres, and Bhakta, (2011) reported incorporating educational games into instruction developed significant increases in cardiology, infectious diseases, and pharmacy practice assessment scores. Bhaskar (2014) found that the game helped students improve their understanding of blood grouping to review their existing knowledge. Osier (2014) reported that the educational game has a significant effect on students' performance of genetic terms. Carew (2018) game was a method for comprehension of physiology. The results of these studies with different student groups in various aspects of biology reveal that educational games can be used to support traditional teaching and learning of students in the teaching process.

Biology students often have difficulty grasping biological concepts. For example, many students need to memorize complex words to understand the topic, which distracts them from the lesson [17]. For this reason, methods to ensure students' motivation and participation should be incorporated into the teaching process. The topic of Kingdoms of LivingThings, a ninth-grade biology unit in which students experience difficulties in learning, was examined in this study. In teaching this unit, five fun and educative games that contributed to students' learning of this unit and increase their interest [25], were developed to reinforce and review the concepts in the unit through utilizing attractive methods. The study investigated the use of educational games on the students' achievements and the retention of knowledge, as well as their views on the use of educational games.

\section{Method}

The study was designed as a multi method study that utilized a quasi-experimental design with pre- and post-test control group, and descriptive qualitative research method.

\subsection{Participants}

68 ninth grade students participated in the study from an Anatolian high school in Turkey, and 34 students were included in each of the experimental and control groups. Participants in the study were identified by convenience sampling method in the high school which the second researchers perform as a teacher. Two ninth grade classes were randomly assigned as the experimental and control group. A total of 15 of the students were male, and 19 were female for each group. The students' ages ranged from 14-15 years.

\subsection{Data Collection Tools}

The Achievement Test developed by the researchers, the view form on the use of educational games and research observation diary were used to collect data.

\section{Kingdoms of Living Things Achievement Test}

In the preparation and design process of the achievement test, a table of specifications indicating the objectives of the Kingdoms of Living Things unit in the ninth-grade biology curriculum was developed. For the validity of test the distribution of questions about the learning objectives was determined according to the weight of each objective to the overall unit; therefore, the Kingdoms of Living Things Achievement Test, comprising 35 multiple-choice questions, was developed by the researcher. Opinions of one biology education field expert and three biology teachers about the questions' scientific appropriateness and content validity were considered. Furthermore, two Turkish language and literature teachers also examined the questions in terms of language and expression. Based on their feedback, necessary adjustments were made to the test. The reliability investigation of the corrected and finalized form of KLTAT was carried out with 176 tenth-grade students from an Anatolian high school. The item analysis was made for the data obtained, and the item difficulty and discrimination indices (rjx) were calculated using ITEMAN 4 software. After completing the item analysis for each item, the distracter of three items whose discriminative indices were between 0.20 and 0.29 was readjusted and these final versions were included in the test. A Cronbach $\alpha$ reliability coefficient of 0.87 was found for the entire test. The item analysis revealed an average item difficulty of 0.570 and an average item discrimination of 0.580 , which indicated that KLTAT yields valid and 
reliable results.

\section{Observation Diary}

An observation log recorded the second researcher's observations during each game. The researcher observed the course of each game, discussions taking place during games, students' reactions, and the reflections of the teaching and learning processes, and recorded these observations in the observation log.

\section{View Form on the Use of Educational Games}

A view form on the use of educational games, which was developed by the researchers and based on the experts' opinions and related literature, was applied to the students in the experimental group after completing all games. This form comprises four open-ended questions to determine the students' views of the effectiveness of the educational game.

\subsection{Implementation}

The implementation of the study lasted seven weeks as three lesson hours per week. Prior to the implementation, the Kingdoms of Living Things Achievement Test was applied to both groups to determine their equivalence. After applying the pre-test, the lecturing was carried out in the same way in both groups. During this process, the interactive whiteboards and textbooks were used, and essential parts of the lesson were noted down by the students. In the control group, students were required to review the lesson using the question-answer technique and assigning activities in the textbook as an assignment. In the experimental group, on the other hand, educational games were used to assist the review, reinforcement and assessment of the lesson material.

Five different educational games about different sub-topics of the Kingdoms of Living Things unit were developed and used for teaching the experimental group. These games were developed by the researchers based on their imagination and using daily card games and educative web contents. When designing the games, particular attention was paid to the ninth-grade biology course objectives, students' age group and the appropriateness of the game to their level. Necessary changes were made to the games based on the feedback received from one university lecturer (Biology Education), three biology teachers, two classroom teachers and 102 tenth-grade students with whom the pilot study was conducted. The educative card games used in the study were labeled as Bio-Know-Win, Bio-Find-Match, Bio-Taboo, Bio-Risk, and Kingdoms of Living Things, and were implemented in the same order. The games were played at the end of the topic and designed to cover the previous topics as well. Therefore, the previous topics were reinforced by reviewing them with various games. The teachers' role and the implementation stages of educational games were considered in the implementation of these games. For this reason, the tables in the classroom were arranged in clusters to prepare the classroom for the group game. The groups were formed appropriately to the characteristics of the game and the game materials were prepared for each group. The researcher made all necessary explanations and performed an example in order for the students to understand the game. Also, the game instructions in written form were made available on the table of each group. The hourglass was used to measure the time during the game. Particular attention was paid to include the game within the lesson hours. The researcher who administered the game observed the students' behaviors and recorded it in the observation diary.

The achievement test, which was previously applied pre-test, was applied post-test to both groups. In addition, the view form on the use of educational games was applied to the experimental group. Six months after the implementation of the post-test, the test was applied once again to determine the retention of their scores on KLTAT.

\subsection{Data Analysis}

SPSS 17 (Statistical Package for the Social Science) was used to analyze the quantitative data. T-test was used to compare the experimental and control groups' scores on the pre-test, post-test, and retention test scores. Content analysis was used to analyze the qualitative data obtained from the open-ended questions in the View Form on the Use of Educational Games. The researchers conducted an in-depth analysis of both the coding schema and codes assigned to the participants and consequently reached a $100 \%$ agreement.

\section{Results}

\subsection{Quantitative Results}

Unpaired samples t-test results regarding the control and experimental group students' pre-test achievement scores are shown in Table 1.

Table 1. Unpaired samples t-test results regarding the control and experimental group students' pre-test achievement scores

\begin{tabular}{ccccccc}
\hline Group & $\mathrm{N}$ & $\overline{\mathrm{x}}$ & $\mathrm{s}$ & $\mathrm{sd}$ & $\mathrm{t}$ & $\mathrm{p}$ \\
\hline Control & 34 & 8.09 & 1.58 & 66 & -.909 & .367 \\
Experimental & 34 & 7.62 & 2.57 & & & \\
\hline
\end{tabular}

No significant difference was found between the control and experimental group students' pretest achievement scores $[\mathrm{t}(66)=-.909, \mathrm{p}>.005]$. This result showed that the control and experimental groups' pretest achievement scores are similar.

Unpaired samples t-test results regarding the control and experimental group students' post-test achievement scores 
are shown in Table 2.

Table 2. Unpaired samples t-test results regarding the control and experimental group students' post-test achievement scores

\begin{tabular}{ccccccc}
\hline Group & $\mathrm{N}$ & $\overline{\mathrm{x}}$ & $\mathrm{s}$ & $\mathrm{sd}$ & $\mathrm{t}$ & $\mathrm{p}$ \\
\hline Control & 34 & 12,09 & 2,72 & 66 & 16,666 &, 000 \\
Experimental & 34 & 26,62 & 4,29 & & & \\
\hline
\end{tabular}

The average score of the experimental group students $(\bar{x}=26.62, s=4.29)$ was higher than that of the control group students $(\bar{x}=12.09, \mathrm{~s}=12.09)$. A significant difference was found between the experimental and control group students' posttest achievement scores $\left[\mathrm{t}_{(66)}=16.666, \mathrm{p}<.005 ; \mathrm{d}=4.05\right]$. The Cohen's $d$ was calculated to determine the effect size of the study and it was found to be 4.05 . According to Cohen (1988), this value indicates a large effect size.

Considering the control and experiment groups' average scores on the pretest and post-test shown in Table 1 and Table 2, it was seen that there is a difference between the averages of the pretest and post-test. The average scores of each group increased after the instruction; however, the increase was higher in the experimental group, which was taught using the educational games.

Unpaired samples t-test results regarding the control and experimental group students' retention test scores are shown in Table 3.

Table 3. Unpaired samples t-test results regarding the control and experimental group students' retention test scores

\begin{tabular}{ccccccc}
\hline Group & $\mathrm{N}$ & $\overline{\mathrm{x}}$ & $\mathrm{s}$ & $\mathrm{sd}$ & $\mathrm{t}$ & $\mathrm{p}$ \\
\hline Control & 34 & 10.91 & 2.44 & 66 & 18.100 & .000 \\
Experimental & 34 & 21.94 & 2.58 & & & \\
\hline
\end{tabular}

$* \mathrm{p}<0.05$

The average score of the experimental group students $(\overline{\mathrm{x}}=21.94, \mathrm{~s}=3.21)$ was higher than that of the control group students $(\bar{x}=10.91, \mathrm{~s}=2.58)$. A significant difference was found between the experimental and control group students' retention test scores $\left[\mathrm{t}_{(66)}=18,100, \mathrm{p}<, 005 ; \mathrm{d}=4,39\right]$. The Cohen's $d$ was calculated to determine the effect size of the study and it was found to be 4.39 . According to Cohen (1988), this indicates a large effect size.

Considering the average scores stated in Table 3 , the averages of the experimental group students were still significantly higher than that of their counterparts in the control group six months later than the implementation.

It has been determined that the educational games used during the teaching of Kingdoms of Living Things Unit contributed significantly to the achievements of the students and also they were effective in maintaining the retention of their achievements. It can be said that the questions and tasks contained in the educational games facilitate the learning of the students by activating the various cognitive processes and increase the retention of knowledge.

\subsection{Quantitative Results}

Results Regarding the View Form on the Use of Educational Games

The question "What are your views on the use of educational games in the Kingdoms of Living Things unit of the biology course?" was posed to the students in the View Form on the Use of Educational Games. Their responses to this question were analyzed and the codes driven based on this analysis are shown in Table 4.

Table 4. Students' Views on the Use of Educational Games

\begin{tabular}{cl}
\hline Students' views & Frequency \\
\hline Games enabled me to learn & 30 \\
\hline Design and content of the games was appealing & 26 \\
\hline Games were entertaining & 25 \\
\hline Games promoted knowledge retention & 22 \\
\hline Games provided collaboration & 20 \\
\hline Games increased my interest in the lesson & 12 \\
\hline Games enabled me to review & 9 \\
\hline Games fostered my motivation & 8 \\
\hline I did not get bored in the lesson at all & 7 \\
\hline Games made me like the lesson & 6 \\
\hline Games boosted my confidence & 2 \\
\hline I corrected my mistakes & 2 \\
\hline Games provided me to participate in the lesson & 1 \\
\hline
\end{tabular}

As Table 4 shows, the students highlighted that $(\mathrm{f}=30)$ the use of educational games promoted their learning. Following that, a vast majority of the students $(\mathrm{f}=26)$ presented opinions on the design and content of games. Also, the students indicated that the games were fun $(\mathrm{f}=25)$, promoted knowledge retention $(\mathrm{f}=22)$, provided opportunities to collaborate $(\mathrm{f}=20)$, and made the lesson enjoyable $(\mathrm{f}=18)$. In addition, some students expressed that the use of educational games enabled them to review, increases their motivation, keeps them engaged in the lesson, and boosts their confidence. Some of the students' views on the first question are shown below. S1 highlighted the contribution of games to learning and stated that he or she liked the games in terms of their form and content while expressing his or her opinions on the use of games.

S1: The games enabled us to understand and learn the topics better. We did not forget what we have learned in the games for a long time. In addition, the games were colorful and clear. It is rather sad that this happens only for the biology course. Playing the games with our peers also enabled us to correct our mistakes. The games were well designed and were at a level that we can understand.

S27, similarly reported that the games improved the 
retention of his or her knowledge and made them understand the importance of collaboration, and reported the following about the games in terms of their form and content:

S27: It was catchy. It caused us to like the biology course. We also understood the importance of group study. We expressed what we know in a better way. It provided us to find different alternatives. The games made us review and therefore reinforce the topic. The games were quite colorful. It was appropriate to our level, which enables us to play the games with fun.

S13 and S18 expressed that the games made them enjoy the lesson and encouraged communication with their peers, in addition to improving their understanding of the topic.

S13: The games were beautiful. I entertainingly played with my friends by learning. It helped us to comprehend the lesson better. My communication with my friends increased. It caused me to more like the biology course. My self-confidence was fostered with the games.

S18: Our interest in the biology course increased with the visually enriched and entertaining games. We learned the topics more easily. We did not get bored in the lesson. Our motivation increased; therefore, all these reflected our exams well. Our relationship with our friends strengthened. I like to see and play the games once again.

Table 5. Students' Views on the Contributions of Learning with Educational Games

\begin{tabular}{cc}
\hline Students' Views & Frequency \\
\hline Games made easier to learn. & 19 \\
\hline Games provided knowledge retention & 19 \\
\hline Games enabled me to have fun & 14 \\
\hline Games provided me to be active in the lesson & 12 \\
\hline My interest in the lesson increased & 11 \\
\hline I collaborated with other students & 11 \\
\hline I became engaged in the lesson & 9 \\
\hline My motivation increased & 8 \\
\hline I corrected my mistakes & 8 \\
\hline My self-confidence was boosted & 8 \\
\hline I became more successful & 7 \\
\hline I overcame my deficiencies & 6 \\
\hline I assessed my learning & 5 \\
\hline Games made me enjoy the lesson & 4 \\
\hline
\end{tabular}

Another student (23) stated, "Thanks to the educational games, the topics which are not interesting to me become more entertaining and joyous. My interest and participant in the lesson even more increased. Competition in the course enables us to spend even more entertaining and joyous time." This testimony highlights that, in addition to the characteristics of the games mentioned by the other students, the competitive atmosphere created by the games in the classroom was also entertaining to the students.

The question "What kind of contributions did make to you by learning with games?" was also posed to the students. Their responses to this question were analyzed and the codes driven based on this analysis are shown in Table 5 .

As Table 5 indicates, approximately half of the students expressed that the games improved their learning experience by facilitating learning, providing knowledge retention, and increasing motivation. Moreover, some students indicated that the games promoted active participation in the lesson, collaboration with their peers, learning without getting bored, boosted self-confidence, overcoming deficiencies and mistakes, and assessing their own learning. The views of some students on the second question are shown below. For example, S3 states that the games promoted their active participation and expressed their views as follows: "My interest in the lesson increased. My relationships with my friends developed with these beautiful games. We even more socialized with each other. Now, I am much more active in lessons. I had a chance to identify all things. It would be better if the lessons are taught with games." Another student (S5) stated that in addition to improving their memory of the lesson, the games enable the development of some skills and expressed his or her views on this issue as follows: "I can easily recall the knowledge I was not used to be able to keep in my mind. My skills of speaking and explaining increased. I recognized my mistakes and deficiencies during the games and therefore had a chance to correct them."

Some students expressed that during the lessons, they were engaged, had fun while learning, and that their interest and motivation towards the lesson increased. Of those students, S6 and S14 explained their views on this issue as follows:

S6: Learning the lessons with games was quite entertaining and educative. I had a chance to assess my learning since I participated in the game myself. I tried to overcome my deficiencies. My interest in the biology course increased. I was eager to come to lessons. I tried to listen to the topics more carefully because I tried to score higher by answering the questions in the games.

S14: It enabled us to learn in the lesson without getting bored since we lost track of time. I was able to express myself in the game. I liked this very much. We were able to reach a higher success forming groups with my friends, which made me very happy.

S24: My self-confidence boosted. It helped me to recall the topics. My interest in the lesson increased. Thanks to these games, my motivation and interest in learning increased. My attention during the lesson deepened.

Considering the students' statements, it was clear that 
the use of educational games during the lessons positively influenced their learning.

The question "Was there any moment during the game which negatively influenced you?" was posed to the students. The games were not perceived to have a negative effect.

Lastly, the question "How do you compare the educational game method and other methods used in the lesson?" was posed to the students. The students compared the educational games with other traditional methods and listed the characteristics of educational games, as seen in Table 6 .

Table 6. Students' Views on the Comparison of the Use of Educational Games and Other Methods

\begin{tabular}{cc}
\hline Students' views & Frequency \\
\hline It is effective in learning & 27 \\
\hline It is not monotonous/boring & 25 \\
\hline It is entertaining & 17 \\
\hline It promotes knowledge retention & 15 \\
\hline It encourages active participation & 11 \\
\hline It is interesting & 8 \\
\hline It increases motivation & 8 \\
\hline It made the lesson interesting & 6 \\
\hline It promoted collaboration with my \\
peers & 4 \\
\hline It develops self-confidence & 2 \\
\hline
\end{tabular}

A vast majority of the students expressed that the use of educational games promoted effective learning $(\mathrm{f}=27)$ and they are not boring $(\mathrm{f}=25)$. Some students are of the opinion that the use of educational games outclasses other methods when compared because educational games are entertaining, promote knowledge retention and active participation, are interesting, increase motivation, make one to like the lesson, provide collaboration, and boost self-confidence. The students' statements revealed that traditional methods used in lesson often caused them to get bored, made them unable to apply themselves in the lesson, moved away them from the lesson, and prevented their participation in the lesson. S2 and S6, who are of this opinion, explained their views as follows:

S2: The educational game method, compared to other methods used in lessons, provided us to learn in a more entertaining way and made this learning more permanent. While other methods made us bored in the lessons and caused us to aspire for the break time, we lost track of time during the educational games and aspired to the next game. It is a very successful method.

S6: Other lessons are very boring since the teacher always lecture and I detach myself from the lesson, I become off. In the games, however, I was able to learn easily in an entertaining way without getting bored. Together with my friends, we scored good points using our knowledge. I was able to express myself. Since I am a silent student, I was not that able to participate in the lesson.

S6 highlighted that in addition to preventing lessons from being boring, the games enabled him or her to express him or herself better and encouraged his active participation. Similar, S20 reported, "Most of us become off during the lessons since the teacher often starts with lecturing then make us write. However, when we learned our lessons with games, our learning become more permanent and our visual memory developed. Since we learned with fun, I even lost track of time, which increased my motivation. I want to participate in lessons more than it was always before." S17 also stated that educational games during the lesson increased his or her motivation towards the lesson and promoted learning: "I do not find other methods used in lessons effective because I at most apply myself for 20 minutes while the teacher lectures on the board. At the half of the lesson, I do not understand the topic, unfortunately."

Some students argued that educational games are very appropriate for the biology course and made them like the lesson. Some students (S15, S28, S19, S25, S26, S21, S8, S27, S4, S3, and S11) proposed that this approach to learning should be applied to all courses. For example, S15 stated that "I think that games are very effective primarily in making one like the lesson. Teachers only lecture in other lesson and do not use any visual material. However, we learned the biology lesson with visual cards, games and competitions. I wish it to be the same for other courses."

The students indicated that educational games are useful and more effective compared to other methods. They added that traditional methods are boring and prevented them from focusing. On the contrary, they learn better when active in games; thus, games support their retention of knowledge. The following student statement (S22) supports this:

S22: I think that educational games are better compared to traditional lesson methods because we do not get bored in the lesson. Lessons become more entertaining and therefore more efficient. I study to win the game and this makes my learning more permanent. This system is awesome. I learned with fun. This was also beneficial for my exams.

The opinions of the students about the educational games are quite positive as understood from the above expressions. The students found the games informative, entertaining and reinforcing their learning, and stated that they are effective in enabling the retention of new knowledge, promoting collaboration with their peers, and increasing their interest and motivation for learning These positive characteristics of educational games perceived by students may have contributed to the cognitive learning by affecting the affective characteristics of the students.

When playing the games, the students' behaviors and 
reactions were observed and recorded in the observation log. Results from the observation of each game are presented below.

During the Bio-Know-Win game, it was observed that the students were quite eager and focused on the game. It was noteworthy that the group members established effective communication amongst each other and that silent students became more active and made an effort to answer the questions. The students seemed to be impatient for their turn to play the game and they listened to the game questions quietly and carefully. No noise or disruptions took place in the classroom and the game proceeded as planned. Most of the students wanted to play the game again once their turn had ended. While playing the Bio-Know-Win game, the students were observed to be motivated, collaborated and communicated with their peers, and had fun.

During the Bio-Find-Match, the students followed the cards opened by other students with a great attention. Some students were unable to match the cards because he or she did not recognize the visual of a living thing despite his or her knowledge of its characteristics. In addition, enlivened and productive dialogues took place among students. Upon completing the game, the groups requested to play again. All students were active and had fun during the game. In particular, the students who barely participated in lessons (S4, S6, S10, S14, S22, S29, S32) actively participated in the game and were successful.

During the Bio-Risk game, the students were quiet at first. However, as the game proceeded, their excitement increased and the overall classroom environment was transformed. This, however, did not cause noise or disruptions. As the score gap between the groups enlarged, the students became impatient and made an effort to respond to the questions correctly. The students followed the rules and a respectful attitude was observed among the competing groups. The students tried to develop strategies to score higher during the game and avoided selecting risky questions. Even though three students stated that they did not like that players could go bankrupt in the game, it was observed that the bankrupt cards made the game more entertaining and competitive. When asked questions by the researcher, some students had the chance to correct their mistakes. The students expressed that they had a great time and that they would like to play the game once again. Some students continued playing the game during the break.

The Bio-Taboo game involved all unit topics and was therefore played at the end of the unit. Most of the students expressed that they had a lot of fun during this game as they did in other games. It was noted that explaining the words in a scientific manner made a considerable contribution to the students' comprehension of the topic. During the game, it was monitored that the students have a great time in expressing the words of the taboo cards. It was remarkable that the students who had barely participated in previous lessons performed well in the game. The students experienced a very active and fluent process in the game. During the game, the students seemed to be comfortable, expressed themselves without any difficulty, and exhibited a good relationship between them. They easily recognized the living things on the cards that am I and also experienced exciting times with the chance cards. All groups completed the game at approximately the same time. Some students stated that they wanted to play the game again.

The Kingdoms of Living Things game requires students to match visuals with living things in the classification schema while they have fun without experiencing any difficulty. The students were asked to recognize the visual of living things, including all kingdoms learned throughout the unit. All students, without any difficulty, were able to put the living things whose visual is given under the correct kingdom. The game proceeded fluently and created a competitive environment. It was observed that the students carried out the classification of the visual with great attention. During the classification, other students cheered to support their friends.

The students were observed to have fun during each game, and their interest in the topic and learning increased. In addition, they actively participated in the teaching process, collaborated and communicated with their peers, and students who did not participate in the lessons where traditional methods are performed began to participate in the lesson with the help of educational games.

\section{Conclusions and Discussions}

This study investigated the effect of the use of multifaceted and entertaining educational games to review and reinforce students' knowledge of the Livings Things Universe unit on their academic achievement and knowledge retention. The results revealed a significant difference in favor of the experimental group students. The results of the retention test, which was applied six months after the implementation, also corroborated this result. It was also found that educational games increased students' achievement and served as an effective tool for promoting the retention of new knowledge. Similarly, Liu and Chen (2013) in their study conducted with primary school students investigated students' performance in learning science-related concepts using a card game. They found that the game was effective and increased students' academic success and their knowledge retention. In a different study, Lewis, Peat, and Franklin (2005) used interactive game cards to teach protein synthesis to freshman biology students. At the end of the lesson implementation, it was showed that by using games the learning takes place more easily. Spiegel et al. (2008) reported that educational games serve as an alternative approach to teaching complex cell and molecular biology topics to secondary school students. Osier (2014) put forward that the educational game designed by university 
students to review basic terms and vocabulary about genetics has a significant effect on students' performance. Similar to this study, Su, Cheng, and Lin (2014)'s study, conducted with eleventh-grade students, found that the use of educational games has a noticeable potential to facilitate students' learning of how the immune system functions, and that students who learned through playing the game are significantly more successful than their counterparts. As corroborated by the results of this study, $\mathrm{Su}$, Cheng, and Lin (2014) revealed that their participants' perceptions towards game-based teaching and teaching activity and think that game-based lessons were positive, as they reported them to be much more interesting than traditional didactic lessons. Cardoso et al. (2008) posited that games support high school students' learning of molecular biology and constitute a more active learning profile. The participants of the aforementioned study also added that games are an easy and interesting tool to learn the topic. Cavalho, Beltramini, and Bossolan (2018) investigated the contribution of games to high school students' conceptual understanding of protein synthesis. They found that games help students to achieve conceptual objectives and to develop a model of protein synthesis and that collaborative and competitive interaction raised by games can encourage students' meaningful and future learnings. They concluded that games with these characteristics can be used as a didactic tool in classrooms.

The students in the experimental group commented on the use of educational games during lessons. Their responses and interpretations revealed that the use of educational games in the teaching process helps students to learn and improve certain skills, as well as increase their academic success and knowledge retention. The students listed the benefits of educational games:

- They make the lesson more entertaining

- They promote collaboration among students

- They encourage active student participation

- They increase motivation towards the lesson

- They make lessons enjoyable and attract attention to the topic

- $\quad$ They encourage effective communication among students

- $\quad$ They facilitate learning and provide visual learning

- They enable students to express themselves

- They help students to reinforce their knowledge by reviewing the topics

- They keep students engaged in the material

- They empower students to correct their own mistakes

- They enable to overcome challenges

- They boost students' self-confidence

Similar to those found in this study, many studies in the related literature on using games to teach various topics $[2,3,4,5,7,8,15,17,18,19,20,21,22,23,24,32,35,37,38]$

report that teaching with games enhances students' motivation as well as increases their motivation, promotes active participation in lessons and the development of positive attitudes, and makes lessons more entertaining and pleasant.

However in real life games have a winner and loser, there is actually no loser in educational games. Because by educational games students learn many scientific concepts and methods and also develop positive attitude towards science [14]. Su, Cheng, and Lin (2014) reported that an effective learner requires motivation to participate in the learning activity and to use various strategies to facilitate his or her own learning. In this regard, educational games can be used as an effective and powerful tool for students and as an approach to support the traditional teaching of biology, which has a rich content in terms of abstract concepts and terms. This is because cognitive processes are very influenced by emotions and there is a deep relationship between emotional variables and learning process. Therefore, it was thought that the use of educational games enhances motivation and consequently contributes to the development of positive perceptions that are necessary for learning [15].

Games are considered a profoundly motivating approach to learning that contains elements of individualistic and team competition. Through games, participants are provided with a constructed experience which enables them to learn from what they do, rather than what they are [1]. Since games enable students to think about their peers' behaviors and to reinforce their team skills, students also facilitate their own learning [7]. Some students in this study also stated that thanks to the games, their learning was facilitated; they overcame their challenges, corrected their mistakes, reinforced their learning and had an opportunity to assess their learning. In this study, it was noticed that some games provided an environment for healthy competition between the students, which promoted students' decision-making processes. Since the decisions made affected their progression in the game, the students developed strategic skills. Some of the students emphasized that the increased collaboration with their peers was another positive characteristic of the games. Considering the fact that the intervention of the teacher and peers is essential for students' development according to Vygotsky's sociocultural theory, the use of games as a pedagogical resource can be regarded as an important educational activity in terms of providing the collaboration among students [12].

In this study, five games about a unit were developed and implemented to reveal the role of games in learning. It might not be possible to design games for each unit. However, various educational games can be designed using simple and cost-effective materials, such as those in this study, for concept-rich topics which students experience difficulties to learn. In this way, students' motivation to learn, as well as some of their social characteristics, can be enhanced. In addition, the games designed can be used for future students. 


\section{REFERENCES}

[1] Allery, L. (2014). Make use of educational games. Education for Primary Care, 25(1), 65-66.

[2] Aycan, Ş., Türkoğuz, S., Arı, E., \& Kaynar, Ü. (2002). Periyodik cetvelin ve elementlerin tombala oyun tekniği ile öğretimi ve bellekte kalıcılığının saptanması. V. Ulusal Fen Bilimleri ve Matematik Eğitimi Kongresi, Orta Doğu Teknik Üniversitesi, Ankara.

[3] Barclay, S. M., Jeffres, M. N., \& Bhakta, R. (2011). Educational card games to teach pharmacotherapeutics in an advanced pharmacy practice experience. American Journal of Pharmaceutical Education, 75(2), 33.

[4] Bayir, E. (2014). Developing and playing chemistry games to learn about elements, compounds, and the periodic table: Elemental Periodica, Compoundica, and Groupica. Journal of Chemical Education, 91(4), 531-535.

[5] Beylefeld, A. A., \& Struwig, M. C. (2007). A gaming approach to learning medical microbiology: students' experiences of flow. Medical Teacher, 29(9-10), 933-940.

[6] Bhaskar, A. (2014). Playing games during a lecture hour: experience with an online blood grouping game. Advances in Physiology Education, 38(3), 277-278.

[7] Burleson, K. M., \& Olimpo, J. T. (2016). Clue Connect: a word array game to promote student comprehension of key terminology in an introductory anatomy and physiology course. Advances in Physiology Education, 40(2), 223-228.

[8] Can, S. \& Yıldırım, M. (2017). Eğitsel Oyunlarla Fen Dersine "Var Misın Yok Musun?" Atatürk Üniversitesi Kazım Karabekir Eğitim Fakültesi Dergisi, 35, 14-30.

[9] Cardona, T., Spiegel, C. N., Alves, G. G., Ducommun, J., Henriques - Pons, A., \& Araújo - Jorge, T. C. (2007). Introducing DNA concepts to Swiss high school students based on a Brazilian educational game. Biochemistry and Molecular Biology Education, 35(6), 416-421.

[10] Cardoso, F. S., Dumpel, R., da Silva, L. B. G., Rodrigues, C. R., Santos, D. O., Cabral, L. M., \& Castro, H. C. (2008). Just working with the cellular machine: a high school game for teaching molecular biology. Biochemistry and Molecular Biology Education, 36(2), 120-124.

[11] Carew, M. (2018). Using a word game to test physiology comprehension. Advances in Physiology Education, 42(3), 464-465.

[12] Cavalho, J. C. Q. D., Beltramini, L. M., \& Bossolan, N. R. S. (2018). Using a board game to teach protein synthesis to high school students. Journal of Biological Education, 52, $1-12$.

[13] Cohen, J. (1988). Statistical power analysis for the behavioral sciences. 1988, Hillsdale, NJ: L. Lawrence Earlbaum Associates, 2.

[14] Fazlioglu, Y., Bayir, E., \& Günșen, G. (2016). Teaching Preschoolers Science through Play. In E. Atasoy, R. Efe, I. Jażdżewska \& H. Yaldır (eds.), Current Advances in Education, (603-616). Sofia: St. Kliment Ohridski
University Press.

[15] Franco-Mariscal, A. J., Oliva-Martínez, J. M., Blanco-López, Á., \& España-Ramos, E. (2016). A game-based approach to learning the idea of chemical elements and their periodic classification. Journal of Chemical Education, 93(7), 1173-1190.

[16] Glynn, S. M., Aultman, L. P., \& Owens, A. M. (2005). Motivation to learn in general education programs. The Journal of General Education, 54(2), 150-170.

[17] Gutierrez, A. F. (2014). Development and effectiveness of an educational card game as supplementary material in understanding selected topics in biology. CBE-Life Sciences Education, 13(1), 76-82.

[18] Jones, J. S., Tincher, L., Odeng-Otu, E., \& Herdman, M. (2015). An educational board game to assist PharmD students in learning autonomic nervous system pharmacology. American Journal of Pharmaceutical Education, 79(8), 114.

[19] Karamustafaoğlu, O. \& Kaya, M. (2013). Eğitsel oyunlarla 'yansıma ve aynalar' konusunun öğretimi: yansımalı koşu örneği. Araştırma Temelli Etkinlik Dergisi (ATED), 3(2), 41-49.

[20] Kavak, N., \& Yamak, H. (2016). Picture chem: Playing a game to identify laboratory equipment items and describe their use. Journal of Chemical Education, 93(7), 1253-1255.

[21] Kaya, S. \& Elgün, A. (2015). Eğitsel oyunlar ile desteklenmiş fen öğretiminin ilkokul öğrencilerinin akademik başarısına etkisi. Kocaeli Üniversitesi Eğitim Fakültesi, Kastamonu Ĕ̆itim Dergisi, 23(1), 329-342.

[22] Kurushkin, M., \& Mikhaylenko, M. (2015). Chemical Alias: An Engaging Way to Examine Nomenclature. Journal of Chemical Education, 92(10), 1678-1680.

[23] Lewis, A., Peat, M., \& Franklin, S. (2005). Understanding protein synthesis: an interactive card game discussion. Journal of Biological Education, 39(3), 125-130.

[24] Liu, E. Z. F., \& Chen, P. K. (2013). The effect of game-based learning on students' learning performance in science learning-A case of "Conveyance Go". Procedia-Social and Behavioral Sciences, 103, 1044-1051.

[25] Lujan, H. L., \& DiCarlo, S. E. (2006). Too much teaching, not enough learning: what is the solution? Advances in Physiology Education, 30(1), 17-22.

[26] Odenweller, C. M., Hsu, C. T., \& DiCarlo, S. E. (1998). Educational card games for understanding gastrointestinal physiology. Advances in Physiology Education, 275(6), S78.

[27] Ogershok, P. R., \& Cottrell, S. (2004). The pediatric board game. Medical Teacher, 26(6), 514-517.

[28] Olimpo, J. T., Davis, S., Lagman, S., Parekh, R., \& Shields, P. (2010). Learning can be all fun and games: Constructing and utilizing a biology taboo wiktionary to enhance student learning in an introductory biology course. Journal of Microbiology \& Biology Education, 11(2), 164-165.

[29] Osier, M. V. (2014). A Board Game for Undergraduate Genetics Vocabulary and Concept Review: The Pathway 
Shuffle. Journal of Microbiology \& Biology Education, 15(2), 328.

[30] Patel, J. (2008). Using game format in small group classes for pharmacotherapeutics case studies. American Journal of Pharmaceutical Education, 72(1), 21.

[31] Persky, A. M., Stegall-Zanation, J., \& Dupuis, R. E. (2007). Students' perceptions of the incorporation of games into classroom instruction for basic and clinical pharmacokinetics. American Journal of Pharmaceutical Education, 71(2), 21.

[32] Şaşmaz Ören, F., \& Erduran Avc1, D. (2004). Eğitimsel oyunla öğretimin fen bilgisi dersi "güneş sistemi ve gezegenler" konusunda akademik başarı üzerine etkisi. Ondokuz Mayıs Üniversitesi Eğitim Fakültesi Dergisi, 18, 67-76.

[33] Selby, G., Walker, V., \& Diwakar, V. (2007). A comparison of teaching methods: interactive lecture versus game playing. Medical Teacher, 29(9-10), 972-974.

[34] Spiegel, C. N., Alves, G. G., Cardona, T. D. S., Melim, L. M., Luz, M. R., Araújo-Jorge, T. C., \& Henriques-Pons, A.
(2008). Discovering the cell: An educational game about cell and molecular biology. Journal of Biological Education, 43(1), 27-36.

[35] Su, T., Cheng, M. T., \& Lin, S. H. (2014). Investigating the effectiveness of an educational card game for learning how human immunology is regulated. CBE-Life Sciences Education, 13(3), 504-515.

[36] Ülküdür, M. A. (2016). Proje tabanlı öğrenme etkinlikleri ile oyun tabanl öğrenme etkinliklerinin akademik başarı, tutum ve motivasyona etkisi. Yüksek Lisans Tezi, Amasya Üniversitesi Fen Bilimleri Enstitüsü, Amasya.

[37] Yıldız, E., Şimşek, Ü. \& Araz, H. (2016). Dolaşım sistemi konusunda eğitsel oyun yönteminin kullanılmasının öğrencilerin akademik başarı ve fen öğrenimi motivasyonu üzerine etkisi. Mustafa Kemal Üniversitesi Sosyal Bilimler Enstitüsü Dergisi, 13(36), 20-32.

[38] Yıldız, E., Şimşek, Ü., \& Ağdaş, H. (2017). Eğitsel oyun entegre edilmiş işbirlikli öğrenme modelinin öğrencilerin fen öğrenimi motivasyonları ve sosyal becerileri üzerine etkisi. Journal of Kirsehir Education Faculty, 18(2), 37-54. 